\title{
Productivity Improvement for the Manufacture of Disposable Medical Material in a South American Country pointing towards Industry 4.0
}

\author{
César Stoll Quevedo, Dr. ${ }^{1}$, Christian Cornejo Sanchez ${ }^{1}$, Wilmer Atoche Diaz, Mg. ${ }^{1}$ y Jonatán Edward Rojas Polo, Mg. ${ }^{1}$ \\ 1Pontificia Universidad Católica del Perú, Perú, cstoll@pucp.pe, cscornejo@pucp.edu.pe,watoche@pucp.edu.pe, \\ jrojasp@pucp.pe
}

\begin{abstract}
The manufacture of disposable medical material in a developing country is a labor-intensive manufacturing process. Quality inspections are based on experts' personal observations, who then decide which products fulfill the required quality. Errors in quality control can have fatal consequences due to the clinical use of the products. Furthermore, we cope with several manufacturing problems that affect demand fulfillment. In this context, we need an efficient production line with reliable quality control processes, i.e. a lean production system, no wastes. Implementing the concepts of Industry 4.0 is therefore recommended for a continuous improvement process in the disposable medical material industry. In the cur-rent research, we introduce automated assembly machines as a first step to establish new standards for production and quality. Furthermore, we analyze the long-term benefits based on the application of automation, lean production and Industry 4.0.
\end{abstract}

Keywords-- Productivity, Industry 4.0, lean production.

\section{INTRODUCTION}

Public health in developing countries usually copes with shortages of disposable medical material. Large product demand, production inefficiency, deficient road and communication systems, unexpected severe weather conditions and other difficulties affect the supply of disposable medical material supply. One of the most required disposable medical material is the "infusion set".

The company focus of this study is one of the main suppliers of disposable medical material in Peru. The current assembly line for infusion set is manual, i.e. the production depends on the operator expertise. As consequence, the productivity is low, wastes are large and product quality varies.

The Industry 4.0 concept is more than automated machines. The cyber-physical systems must communicate and cooperate with each other and with humans in real time [1]. In order to focus efforts towards Industry 4.0, in the current study we compare the current production line versus automated assembly lines production. We analyze cost, productivity levels, and product quality. These factors are the key to promote the transfer from manual assembly to automation lines, and furthermore, to a smart factory.

Digital Object Identifier (DOI): http://dx.doi.org/10.18687/LACCEI2018.1.1.233 ISBN: 978-0-9993443-1-6

ISSN: 2414-6390

\section{LITERATURE REVIEW}

Industry 4.0

Current industrial production should be highly flexible and customized - wide integration among customers, companies and suppliers. Furthermore, it needs to be sustainable. The Federal Ministry of Education and Research of Germany defines Industry 4.0 as the flexibility that exists in networks that increase the creation of value through the application of physical systems of cybernetics. [2]. The concept of Industry 4.0 is considered a new industrial revolution, where real-time information is used for com-plex manufacturing systems allowing high customized products in flexible production factories [3].

Industry 4.0 considers real-world application driven by the Internet system and the physical system. In this context, the entire system is affected by the market competitiveness, decision-making, communication, collaboration, etc. [4]. The term Industry 4.0 is associated to an idea of agile and efficient manufacturing processes. This idea is based on the massive use of information and communication technologies [5]. As a consequence, machines in a smart factory can interact with their environments as self-learning devices. These devices are capable of processing data in real time for self-diagnosis and preventing potential interruptions in the production process [6]. The company is therefore highly automatized and computerized, likewise the internal and external processes are interconnected [7].

\section{Medical Devices}

According to The International Medical Device Regulators Forum (IMDRF) the medical devices are "any instrument, apparatus, implement, machine, ... intended by the manufacturer to be used, alone or in combination, for human beings, for one or more of the specific medical purpose(s) of diagnosis, prevention, monitoring, treatment or alleviation of disease ... and injuries..." [8], among other purposes. The IMDRF's definition is also quoted by the World Health Organization (WHO) [9] and further-more, it highlights that "Medical devices save lives, improve health and quality of life ..." [10].

The infusion set is referred to by IMDRF as a medical disposable made of several types of synthetic polymers (plastics). Disposable medical material is typically inexpensive

$1^{\text {th }}$ LACCEI International Multi-Conference for Engineering, Education, and Technology: "Innovation in Education and Inclusion”, 19-21 July 2018, Lima, Peru. 
and prevents the spread of infectious agents. Consequently, current medical material is being replaced for disposable medical devices [11].

\section{Lean concepts and tools before Industry 4.0}

In order to successfully change the company standards into Industry 4.0, lean concepts must be established first. Therefore, it is necessary to identify, eliminate or minimize all sorts of non-value-added activities. Concepts like 5S, Kaizen, process map-ping and value stream mapping, etc. are necessary to maximize process flow and to eliminate waste and control variations. In the particular case of the health sector, the costs must be reduced and quality and reliability improved, which in turn will result in customer satisfaction [12].

\section{Case Study: Manufacture of Disposable MEDICAL MATERIAL}

\section{a) Product description}

In Peru, AB S.A. is one of the main suppliers of disposable medical material for Peruvian health institutions. The current case study is focused in the manufacturing of an "infusion set" (Figure 1).

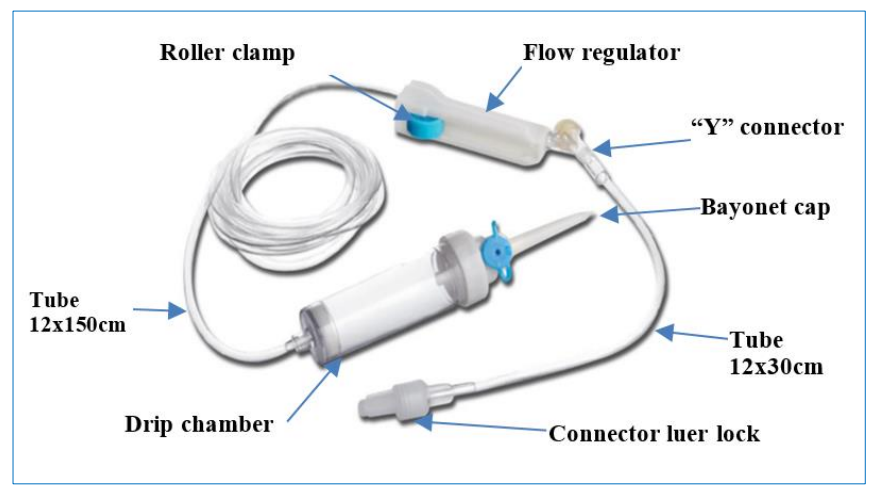

Fig. 1 Infusion set parts.

\section{b) Product assembly}

Most of the parts used in the assembly process are highprecision Italian parts. The only parts produced in the country are the plastic tubes, see Figure 1: tube $12 \times 150 \mathrm{~cm}$ and tube $12 \times 30 \mathrm{~cm}$.

A general description of the assembly process for infusion set is the following: place the bayonet cap at the top of the drip chamber (Part A). Then, place the cap luer lock to the luer lock connector (Part B). The roller must be placed in the clamp, and connected to the $12 \times 150 \mathrm{~cm}$ tube (Part C). Next, Part A and Part $\mathrm{C}$ must be joined (Part AC). One side of the $12 \times 30 \mathrm{~cm}$ tube is joined to Part $\mathrm{B}$ and the other side to the "Y" connector, (subassembly named Part D). Finally, Part AC and Part D are joined, i.e. the infusion set is assembled.

Table 1 shows the operations and standard time required for the assembly of the infusion set.
TABLE I

Operations and standard times

\begin{tabular}{llcc}
\hline Operation & Description & $\begin{array}{l}\text { Minutes / } \\
\text { unit }\end{array}$ & $\begin{array}{l}\text { Production rate } \\
\text { units per min. }\end{array}$ \\
\hline 1 & Put the luer lock cap (Part B) & 0.055 & 18.09 \\
\hline 2 & $\begin{array}{l}\text { Glue the luer lock at one end of } \\
\text { the tube 12x30cm }\end{array}$ & 0.314 & 3.17 \\
\hline 3 & $\begin{array}{l}\text { Glue the "Y" connector with the } \\
\text { other end of the tube 12x30cm } \\
\text { (Part D) }\end{array}$ & 0.324 & 3.08 \\
\hline & $\begin{array}{l}\text { Assemble flow regulator with } \\
\text { tube 12x150cm (Part C) }\end{array}$ & 0.123 & 8.07 \\
\hline 5 & Put the bayonet cap (Part A) & 0.055 & 18.09 \\
\hline 6 & $\begin{array}{l}\text { Glue the tube 12x150cm to the } \\
\text { drip chamber (Part AC) }\end{array}$ & 0.082 & 12.16 \\
\hline 7 & $\begin{array}{l}\text { Glue the tube 12x150cm with } \\
\text { "Y" connector "Y" (Part AC + }\end{array}$ & 0.052 & 18.97 \\
\hline 8 & Part D= Infusion Set) & 0.225 & 4.43 \\
\hline 9 & Clean equipment and inspection \\
\hline 10 & $\begin{array}{l}\text { Label code (batch number and } \\
\text { expiration date) }\end{array}$ & 0.132 & 7.54 \\
\hline 11 & Insert label inside the plastic bag & 0.030 & 33.07 \\
\hline 12 & $\begin{array}{l}\text { Insert infusion set to the plastic } \\
\text { bag }\end{array}$ & 0.176 & 5.66 \\
\hline 13 & Put in sterilization basket & 0.233 & 4.28 \\
\hline 14 & Sterilize & 0.204 & 4.90 \\
\hline 15 & Seal and packing bags & 0.117 & 8.51 \\
\hline & Packing box & 0.125 & 7.94 \\
\hline
\end{tabular}

The manual assembly processes for the "infusion set" presents two major difficulties. First, the inspection method for the tube thickness (caliber), and second, the bonding operations. The time and motion study has been carried out and implemented in the firm, nevertheless the productivity performance just improved slightly.

\section{b.1 Methods for caliber inspection}

A Vernier caliber is used to inspect the pipes thickness, but the measure is taken only at both extremes of the tube. The extrusion machine should produce the required thickness along the all tube. Nevertheless, oscillations in the working process may add variations in pipes thickness. If the pipes thickness is not even, the liquid flow along the "infusion set" could change, increasing the risk when using the infusion set.

\section{b.2 Bonding operations}

If the joints are rough or have residues of chemicals, variations in the liquid flow along the infusion set can also appear, i.e. similarly to the previous observation in the caliber inspection method. Furthermore, visual inspections are the only tool to detect possible residues inside the tubes. Consequently, the expertise and attention of operators is essential.

\section{c) Monetary penalties}

The main customer of the infusion set is the State, which charges extra high fees in case of delivery delay. Moreover, worst-case scenario, the State could finish commercial transactions with the company.

$1^{\text {th }}$ LACCEI International Multi-Conference for Engineering, Education, and Technology: "Innovation in Education and Inclusion”, 19-21 July 2018, Lima, Peru. 


\section{Automation Proposal for the CASE Study}

The following automation proposals aim to increase the productivity and to improve quality control in the manufacturing of an infusion set. Figure 2 shows the general assembly process and operations to obtain the infusion set. Basically, there are three main assembly operations.

The current assembly processes are manual. The first one needs 18 operators, the second one needs 7 operators. In both cases, they must work in their stations during 4.8 hours per day. Finally, the last assembly process needs 25 operators, working for 3.2 hours a day.

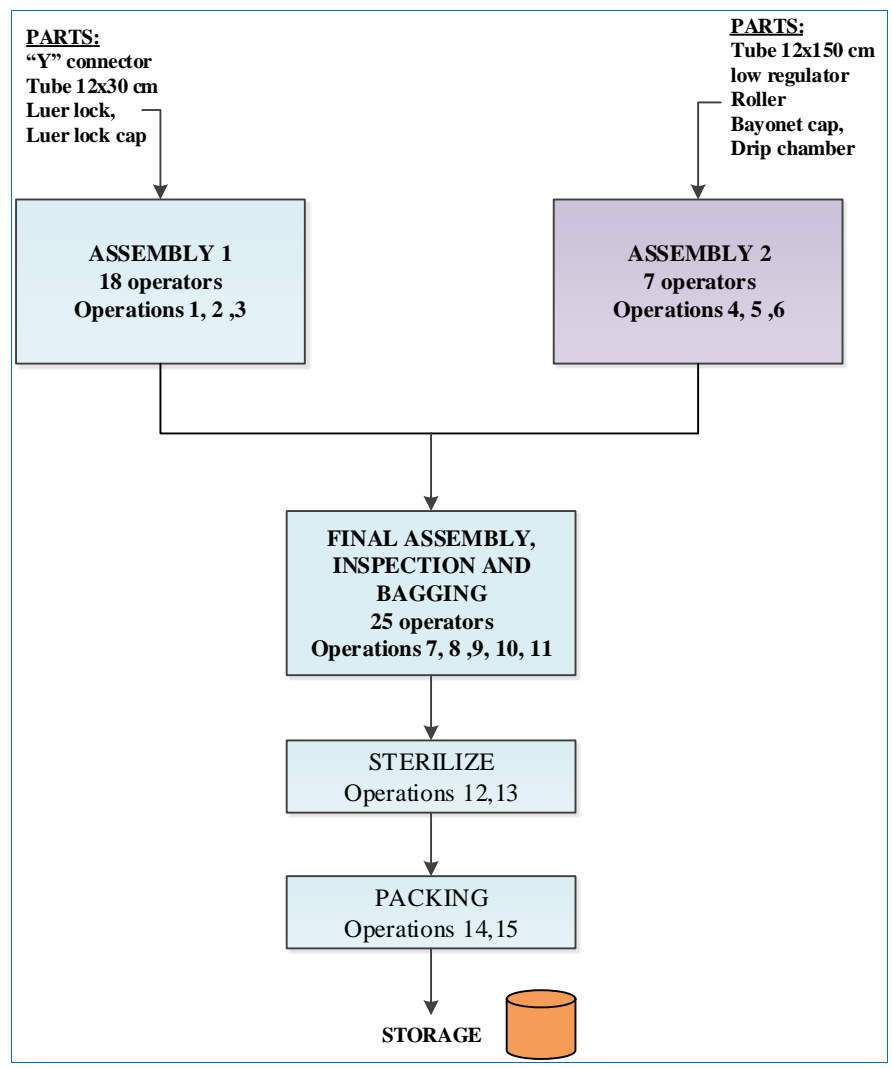

Fig. 2 Infusion set manufacturing block diagram.

The automation proposal for the current case study replaces the manual assembly 1 and 2 with two automation machines. The total number of operators remains the same for comparison. However, the operators' functions are redefined according the new production conditions.

\section{a) First automation proposal}

Figure 3 shows an automation assembly machine, which replaces the manual first assembly (Figure 2) for one machine. This automation machine only needs one worker. The machine is controlled by PLC and has a full automation feeding and testing process for every one-step. The assembly efficiency is 5000 units/hour, and a pass rate up $99 \%$.

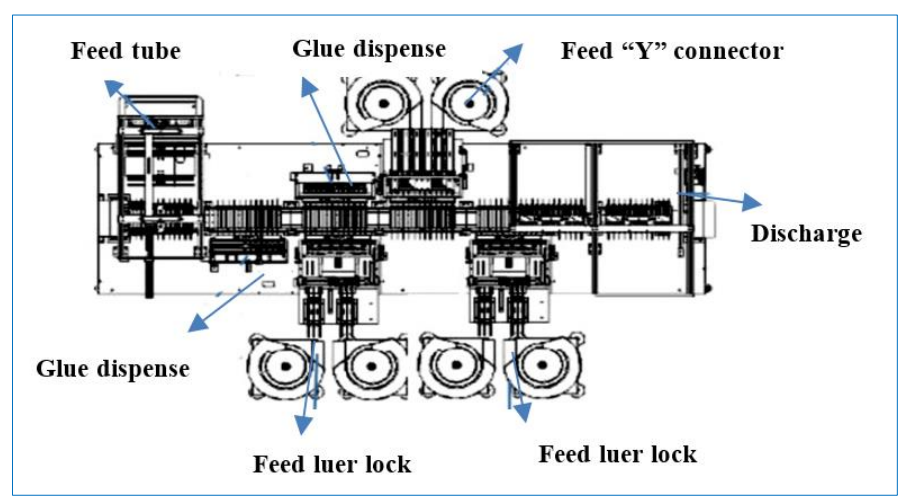

Fig. 3 Automatic machine for first assembly.

Beijia Technology Industrial Co. Limited, 2017

\section{b) Second automation proposal}

Figure 4 shows another automation assembly machine. This replaces the second manual assembly (Figure 2) for one machine. This automation machine needs two workers. The machine is controlled by PLC and has a full automation feeding and testing process for every one-step. The assembly efficiency is 5000 units/hour, and a pass rate up $99 \%$.

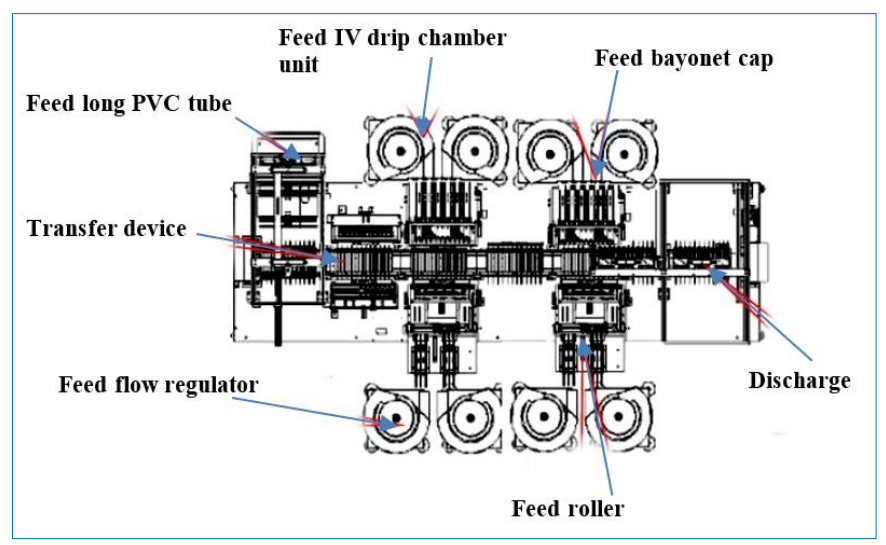

Fig. 4 Automatic machine for second assembly. Beijia Technology Industrial Co. Limited, 2017

\section{RESUlTS AND DisCUSSION}

Tables 2 and 3 show an estimation of the production rate for both cases: manual and automation. The total worker number does not change. However, due to the high performance of the automatic machines, it is necessary to limit the production time production to 4 hours per day, otherwise the inventory will be accumulated.

The current bottleneck in the manual assembly is situated in the second assemble, i.e. 7530 units assembled per day. The

16 $^{\text {th }}$ LACCEI International Multi-Conference for Engineering, Education, and Technology: "Innovation in Education and Inclusion”, 19-21 July 2018, Lima, Peru. 
automation proposal changes the bottleneck to the third manual assembly, i.e. 18274 units assembled per day. Automation of the third manual assembly is beyond the scope of the current study, therefore, further work is necessary.

TABLE 2

Production rate for manual assembly.

\begin{tabular}{llllll}
\hline Assembly & $\begin{array}{l}\text { Standard time } \\
\text { (unit per min.) }\end{array}$ & $\begin{array}{l}\text { Number } \\
\text { operators }\end{array}$ & $\begin{array}{l}\text { Total units } \\
\text { per hour }\end{array}$ & $\begin{array}{l}\text { Daily working } \\
\text { hours }\end{array}$ & $\begin{array}{l}\text { Units } \\
\text { per day }\end{array}$ \\
\hline First & 1.440 & 18 & 1556 & 4.84 & 7778 \\
Second & 3.826 & 7 & 1607 & 4.84 & $\mathbf{7 5 3 0}$ \\
Third & 1.620 & 25 & 2430 & 3.16 & 7679 \\
\hline
\end{tabular}

In the automation scenario, the firm increases its sales quota to the government, health public sector based on the improvement of two factors: Higher production rate and also increase of customer satisfaction regarding product quality.

TABLE 3

Production rate for automation proposal.

\begin{tabular}{llllll}
\hline Assembly & $\begin{array}{l}\text { Standard time } \\
\text { (unit per min.) }\end{array}$ & $\begin{array}{l}\text { Number } \\
\text { operators }\end{array}$ & $\begin{array}{l}\text { Total Units } \\
\text { per Hour }\end{array}$ & $\begin{array}{l}\text { Daily working } \\
\text { hours }\end{array}$ & $\begin{array}{l}\text { Units } \\
\text { per day }\end{array}$ \\
\hline First & 83.33 & 1 & 5000 & 4 & 20000 \\
Second & 83.33 & 2 & 5000 & 4 & 20000 \\
Third & 1.620 & 23.5 & 2284 & 8 & $\mathbf{1 8 ~ 2 7 4}$ \\
\hline
\end{tabular}

Automation machines offer a total inspection of every step of the assembly process, with a pass rate up $99 \%$. Furthermore, it facilitates product exportation to other South American countries, which are liaising with similar shortcomings.

\section{CONCLUSIONS}

The current automation machines offer a huge technological leap in Peru, which can increase commercial transactions. Both proposed machines have an estimated cost of $640,000 €$, including importation fees to Peru. The sale price of the infusion set in Peru is ca. $0.60 €$ per unit. The return of the investment is possible in 4 years provided the firm can cover $90 \%$ of national market and the $35 \%$ of Bolivia and Ecuador market.

The automation technology helps to increase the international competitiveness of the country, i.e. efficiency and effectivity to create value-added. Moreover, once implemented, the technology can be adapted to the manufacturing of a wide range of disposable medical material to fulfill the requirements of an increasingly challenging South American market.

\section{REFERENCES}

[1] Hermann, M., Pentek, T., Otto, B., (2016). Design Principles for Industrie 4.0 Scenarios. In: 49th Hawaii International Conference on System Sciences (HICSS), pp. 3928-3937, IEEE Computer Society Washington DC, USA.

[2] Shrouf, F., Ordieres, J., Miragliotta, G. (2014). Smart Factories in Industry 4.0: A Review of the Concept and of Energy Management Approached in Production Based on the Internet of Things Paradigm. In: Proceedings of the 2014 IEEE IEEM, pp. 697-701, Malaysia.
[3] Dequeant, K., Vialletelle, P., Lemaire, P., Espinouse, M. (2016). A literature review on variability in semiconductor manufacturing: the next forward leap to Industry 4.0. In: Proceedings of the 2016 Winter Simulation Conference (WSC), pp. 2598-2609, Washington DC, USA.

[4] Adeyeri, M., Mpofu, K., Adenuga T. (2015). Integration of Agent Technology into Manufacturing Enterprise: A Review and Platform for Industry 4.0. In: Proceedings of the 2015 International Conference on Industrial Engineering and Operations Management. Dubai, United Arab Emirates (UAE).

[5] Catalán, C., Serna, F., Blesa, F. (2015). Industria 4.0 en el Grado de Ingeniería Electrónica y Automática. In: Actas de las XXI Jornadas de la Enseñanza Universitaria de la Informática, pp. 327-332, Andorra La Vella.

[6] Gökalp, O., Kayabay, K., Akyol, M., Eren, E., Koçyigit, A. (2016) Big data for Industry 4.0: a conceptual framework. In: 2016 International Conference on Computational Science and Computational Intelligence (CSCI), pp. 431-434, Las Vegas, Nevada, USA.

[7] Kagermann, H., Lukas, W., Wahlster, W., (2011). Industrie 4.0: Mit dem Internet der Dinge auf dem Weg zur 4. industriellen Revolution. In: http://www.ingenieur.de/Themen/Produktion/Industrie-40-Mit-InternetDinge-Weg-4-industriellen-Revolution, last accessed 2017/03/01.

[8] The International Medical Device Regulators Forum: Common Data Elements for Medical Device Identification. Final Document International Medical Device Regulators Forum. (2016).

[9] Word Health Organization. Needs assessment of medical devices. Package WHO medical device technical series (2012).

[10]Word Health Organization. Development of medical device policies. Package WHO medical device technical series (2012).

[11]Hanson, J., Hitchcock, R., (2009). Towards Sustainable Design for Singleuse Medical Devices. In: 31st Annual International Conference of the IEEE EMBS, pp. 5602-5605, Minneapolis, Minnesota, USA.

[12]Stankovi, A. (2008). Developing a LEAN consciousness for the clinical laboratory. In: Journal of Medical Biochemistry, Vol. 27 Issue 3, pp. 354359, Franklin Lakes, New Jersey, USA.

16 $^{\text {th }}$ LACCEI International Multi-Conference for Engineering, Education, and Technology: "Innovation in Education and Inclusion", 19-21 July 2018, Lima, Peru. 